Abstracta Iranica Abstracta Iranica

Revue bibliographique pour le domaine irano-aryen

Volume 24 | 2003

Comptes rendus des publications de 2001

\title{
«Les gisements miniers de l'Azerbayjan méridional (région de Taxt-e Soleymân) et la localisation de Gazaka ». BAI 12, 1998 (2001), pp. 249-268.
}

\section{Rémy Boucharlat}

\section{(2) OpenEdition}

Journals

Édition électronique

URL : http://journals.openedition.org/abstractairanica/34361

DOI : 10.4000/abstractairanica.34361

ISSN : 1961-960X

Éditeur :

CNRS (UMR 7528 Mondes iraniens et indiens), Éditions de l'IFRI

\section{Édition imprimée}

Date de publication : 15 mai 2003

ISSN : 0240-8910

Référence électronique

Rémy Boucharlat, « "Les gisements miniers de l'Azerbayjan méridional (région de Taxt-e Soleymân) et la localisation de Gazaka ». BAl 12, 1998 (2001), pp. 249-268. », Abstracta Iranica [En ligne], Volume 24 | 2003, document 93, mis en ligne le 05 janvier 2010, consulté le 25 septembre 2020. URL : http:// journals.openedition.org/abstractairanica/34361; DOI : https://doi.org/10.4000/abstractairanica. 34361

Ce document a été généré automatiquement le 25 septembre 2020.

Tous droits réservés 
« Les gisements miniers de l'Azerbayjan méridional (région de Taxt-e Soleymân) et la localisation de Gazaka ». BAI 12, 1998 (2001), pp. 249-268.

\section{Rémy Boucharlat}

1 À partir de sources très diverses et s'étalant sur tout le premier millénaire de n.è., l'A. revient sur la question de Ganzak/Gazaka, résidence des rois parthes et site sassanide, et son identification avec Takht-i Solaiman. Cette dernière est bien le sanctuaire, création royale du $6^{\mathrm{e}} \mathrm{s}$. que prit le Byzantin Héraclius en 628 , mais, trop petite et peu construite avant cette date, elle ne peut être la ville des auteurs du début de l'ère. Elle est pourtant à localiser dans cette région immédiate, particulièrement importante pour ses mines sur lesquelles l'A. donne un très utile aperçu.

\section{INDEX}

Thèmes : 3.2.3. Séleucides, Parthes et Sassanides 
AUTEURS

RÉMY BOUCHARLAT

CNRS - Lyon 